\title{
Collaborative Management of Implementation of Child Protection Policy in the City of Palangka Raya
}

\author{
Ira Zuraida ${ }^{1}$, Riamona Sadelman Tulis ${ }^{2}$ \\ ${ }^{1,2}$ Lecturers at Public Administration of Social and Political Faculty of University of \\ Palangka Raya \\ ${ }^{1} \underline{\text { ira_pensa@yahoo.com }}{ }^{2}$ monafisip@gmail.com
}

\begin{abstract}
This article aims to examine the policy of child protection in the city of Palangka Raya focusing on data obtained from the Agency of Women's Empowerment, Child Protection, Population and Family Planning of Central Kalimantan, it had been recorded that there were 10 cases of child abuse during January-May 2016 in Palangka Raya. To analyze the factors influencing the implementation of Mayor Regulation Number 17/2013 about Child Protection in Creating a Proper City for Children, it was used Merilee S. Grindle implementation model theory consisting of two variables which determined the success of a policy. The first indicator was the content of the policy and the second indicator was the environment where the policy was implemented.

The findings in the field showed the lack of collaborative management in the Implementation. This was seen in the appropriateness and comprehension of the implementers who were experiencing some constraints like the limited funds, resources, and some public places that did not put any children's interests into priority or educational facilities for children with special needs which were still far from satisfactory. Therefore, it is expected that in the future, the implementers involved in this program will consider the children's interests.
\end{abstract}

Keywords: implementation of policies, Child-Friendly City

\section{Introduction}

As reported by the Central Kalimantan Provincial Women's Empowerment, Child Protection, Population and Family Planning Agency, there were 20 cases of child abuse during JanuaryMay 2016, while Palangka Raya alone recorded 10 cases involving children during JanuaryMay 2016.

This became a particular concern for the Empowerment of Society, Women, Child Protection and Family Planning Agency of Palangka Raya City to propose to the Mayor of Palangka Raya to issue a Mayor Regulation about having a Proper City for Children following up the Ministry Regulation Number 11/ 2011. With the enactment of this Mayor Regulation, it is expected that all children rights can be met properly.

Up to the present, 75 districts/municipalities that are children-friendly have been established in Indonesia and one of the cities that implement them is Palangka Raya. This is stated in Mayor Regulation Number 17/2013 on Child's Protection in order to achieve the Child-Friendly City. The policy stated in the Mayor Regulation Number 17/2013 is the responsibility of all parties and it does not fall to only one specific working unit, therefore it is required that the local government units and other units, including Regional Development Planning Board, Public Health Agency, Civil Registry Agency, the Agency of Empowerment 
of Society, Women, Child Protection and Family Planning, Education Office, Police and other elements work together effectively. it is similar to that delivered by the mayor of Palangka Raya Riban Satia that to reach the city standard worthy of children must have seriousness both between agencies and stakeholders( 24 indicators that must be met by the Local Government of Palangka Raya in order that the city to be called as Child-Friendly. Menara News. Thursday, 16/03/2017 )

\section{Literature Review}

Successful implementation is influenced by two major variables, namely the content of policy (content of policy) and the implementation environment (context of implementation) (Merilee S. Grindle in Nugroho, 2011: 634).

In the first variable is the policy content variable, the success of policy implementation is influenced by various things including:

1. The interests of the target group.

2. Type of benefit

3. The desired degree of change

4. Location of decision-making

5. Implementing the program

6. Resources used

Then on the second variable is the implementation environment, it is said that the policy can not stand alone but the surrounding environment also greatly affect the implementation of policy. Where things in the implementation environment that affect the success of the implementation include:

1. How much power, interests, and strategies do the actors involved in policy implementation have?

2. Characteristics of institutions and authorities

3. Level of compliance and responsiveness (responsiveness).

Collaborative Governance is a process that involves stakeholders who are tied to the interests of each agency in achieving common goals (Cordery, 2004; Hartman et al., 2002). While Anshell and Gash (2007: 544) define Collaborative Governance A governing arrangement where one or more public agencies engage non-state stakeholders in a collective decision-making process that is formal, consensus-oriented, and deliberative and that aims to make or implement public policy or manage public programs or assets.

It can be concluded that Collaborative Governance is a process that involves many elements constructively both from various levels, be it public and private agencies, as well as civil society to achieve public goals 


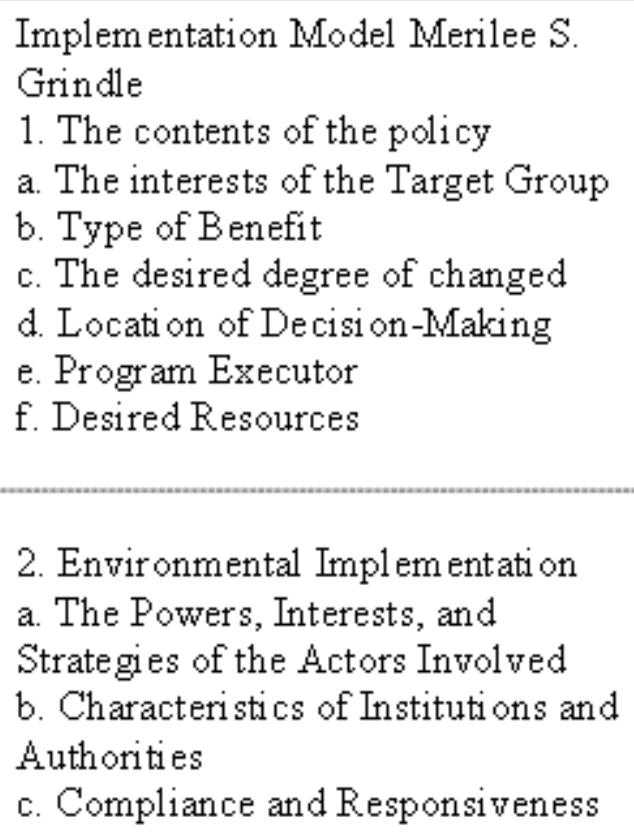

2. Environmental Implementation

a. The Powers, Interests, and Strategies of the Actors Involved b. Characteristics of Institutions and Authorities c. Compliance and Responsiveness

A Framework of Collaborative Management of Implementation of Child Protection Policy in the City of Palangka Raya

\section{Discussion}

\section{The Content of the Policy}

\section{The Interests of the Target Group}

In this section, the target's interest is contained in the content of the policy. In accordance with the Mayor of Palangka Raya regulation, where the target is all children in Palangka Raya City. The researchers took the Children's Forum representing all the children in Palangka Raya City, where this forum also helped the government in suppressing nonviolence and participating in providing aspirations that represented all children in all districts and cities. There was none of importance brought by other parties in the policy created, since it was purely of the government paying attention to all the concepts of children's rights.

\section{Type of Benefit}

The perceived benefits for the Government of Palangka Raya from this Policy are the ability to carry out their roles, functions and responsibilities to put all needed care for the society especially the children. As we know, the government is the servant of society and, according to the objectives of the state, and as which is stated in the 1945 Constitution of the second paragraph concerning the promotion of the common welfare that is the people's welfare. Then, the benefits to society are to get full attention in the needs of their children as the next generation. This can be seen from several aspects of government supports in the development of playgrounds for children such as skate parks and other city parks. The positive impact of the benefits generated by this policy is that the establishment of efforts to fulfill the rights of children by the government and society. This type of benefit can also be 
perceived by the users of facilities provided such as skate park and city parks, because the presence of facilities provided especially for children indirectly provides a space for children to hone their creativity.

\section{The Desired Degree of Change}

Each policy must have a target of how much change it desires to achieve through any implementation of a policy, and it needs to be stated in a clear scale. In the regulation of Mayor of Palangka Raya, the targets to be achieved have been arranged in the Regional Medium-Term Development Plan, therefore it is easier for the government to achieve the targets decided.

The change of this policy is not only expected by policy makers but also by all relevant government agencies from the 5 clusters along with the working units focusing on the development of the Child Friendly City. The examples for this are getting qualified teachers to guide the schoolchildren and the school environment which is expected not to be made of objects that are harmful for children. Furthermore, the children's rights in terms of their environments is that they can have places for any consultation that they might need or orphanages. This is because not all children want to tell their problems to other people, so any establishments of consultation places or institutions for children are necessary. Meanwhile, the hopes from the children themselves that are represented by the hope from the children's forum are that with the existence of this policy, it is expected that the children can be given space, funds and facilities in order to develop their creativity.

\section{Location of Decision Making}

This section explains that this policy is issued by the Mayor of Palangka Raya which refers to the Ministerial Regulation where the Agency of Women's Empowerment, Child Protection, Population and Family Planning as the implementer only runs and coordinates the policy and, in its implementation, coordinates with all local government units and the working units related to the development of the Child Friendly City listed in 5 (five) clusters. In carrying out all policies in the Agency of Empowerment of Society, Women, Child Protection and Family Planning in the city of Palangka Raya, it is the Head of Service which will take any decision that is going to be applied; so as with all the other local government units that implement the policy.

\section{The Program Implementer}

The researchers took a few local government units representing the 5 clusters of the development of Child Friendly City as well as to measure the performance of each implementer in line with the Local Action Plan of Development of Child Friendly City in Palangka Raya in the year of 2014-2018. First, the Civil Rights and Freedom where this cluster refers to the provision of information facilities worthy of children such as to reproduce and develop the reading parks and libraries, playgrounds and sports facilities. In this cluster the implementation is done by all local government units related such as the Department of Transportation and Communications; Civil Service Police Unit; Law Officers; Regional Library and Archive Office; Department of Education, Youth and Sports; Child protection Institution; District Court; Department of Population and Civil Registration; Department of 
Public Relations and Government. Second, the Family Environment and Alternative Care which, this cluster refers to the provision of Consultation Institutions for Parents / Families and Provision of Child Welfare Institutions. In the Cluster of Family Environment Rights and Alternative Care, the implementation is carried out by the Regional Development Planning Board; Society Welfare Department; Public Health Office; Social Service and Employment Agency and Family Consultation Activities Agency. In this study, the focus was on the Social Service and Employment Agency of Palangka Raya City to represent this second cluster, while the results of the study were found related to the Child Friendly City Program in the Department of Social Affairs and Employment, which contributed in the service sector such as child counseling and the responsibility was to foster the orphanages and the institutions under them. From the above findings, it can be understood that the Social Service has performed its duties in the development of Child Friendly City in accordance with the Local Action Plan for the Development of Child Friendly City of Palangka Raya in 2014-2018. However, the programs that encourage the growth of consultative institutions in communities that lead to solutions to violence and child protection are not yet optimal. Third, the Basic Health and Welfare Rights, in which, this cluster refers to the active role in Infant Mortality Rate, Prevalence of Underweight Children under five, the percentage of Exclusive Breastfeeding, the number of Breastfeeding Corners, and the Provision of Non Smoking Areas. In the Basic Health and Welfare Rights cluster, the implementation is done by the Public Health Agency; Water Utilities; Civil Service Police Unit; Department of Transportation and Communications and Department of Education, Youth and Sports. In this study, the researchers conducted a study on the Health Office of Palangka Raya City to represent this third cluster, while the results of research found related to Child Care program were the decreased number of the Infant Mortality Rate in 2016, the raising number of programs applied by Public Health Office in order to resolve the malnutrition problems among toddlers, and an increase in the percentage of exclusive breastfeeding, even though, for the breastfeeding corners provided as well as the non-smoking areas were still a few, in which for this, the Public Health Office needed to cooperate with other local government units. From these findings, there were some conformities in the implementation of the Development of Child Friendly City listed in the development program, in accordance with the Local Action Plan for the Development of Child Friendly City of Palangka Raya in the year of 2014-2018; while for the unconformity was found in the implementation of providing the breastfeeding corners inside offices, even at the Public Health Agency there were no proper spots seen.

Fourth, the Right to Education, Leisure Time Activities and Cultural Art Activities, which in this cluster, the implementation refers to an active role in the Participation Rate of Early Childhood Development (ECD), Percentage of Child Friendly Schools, Percentage of 12-year Compulsory Education, Number of Schools with Programs, Facilities and Infrastructures for Children to and from schools, and facilities for creative and recreative activities that are child friendly, outside of the school that all children can access. In this cluster, the implementation is done by the Department of Education, Youth and Sports; Regional Development Planning Board; Ministry of Religion; Department of Transportation, Communication and Information; Police Department of Republic of Indonesia; Department of Tourism and Water Utilities. Yet, to represent the fourth cluster, the researchers conducted 
the study on the Department of Education, Youth and Sports City of Palangka Raya. The results of the research found related to the program of Child Friendly City was associated with the socialization to the teaching staff about how to teach child-friendly and educational assistance from the center, so that the children can comfortably obtain the education. From the findings, it can be understood that the Department of Education, Youth and Sports City of Palangka Raya has been carrying out its duties in the development of Child Friendly City in accordance with Local Action Plans for the Development of Child Friendly City of Palangka Raya in 2014-2018. Still only one thing to do in which that it needs to adjust the program activities undertaken for children with special needs in Palangka Raya City.

Fifth, Special Protection Rights, which in this cluster, refer to an active role in the disaster management mechanisms that have to consider the importance of children, the children under special protection to obtain the services that they need, and children who have cases under the law, as well as children who were released from the worst forms of child labor. The Special Protection Rights cluster shall be carried out by the Police; Child protection Institution; District Court and Psychologists. However, in this study, the researchers conducted the study on Child Protection Institution of Central Kalimantan Province to represent this fifth cluster; while the result of the research found related to the program of Child Friendly City was that there were a lot of activities undertaken to foster the spirit of children to restore the child's psychological state of trauma due to natural disasters, the Child Protection Institution also cooperated with various agencies in terms of protection services for both victims and suspects as well as mentoring, from reporting to the trial. From these findings, it is concluded that the Child Protection Institution has carried out its duties in the development of Child Friendly City in accordance with the Local Action Plans for the Development of the Child Friendly City Palangka Raya in 2014-2018.

\section{The Desired Resources}

The implementation of a policy should also be supported by sufficient resources in order that the implementation can run well. For the implementation of this policy, the resources of the Agency of Women's Empowerment, Child Protection, Population and Family Planning of Palangka Raya could be said as sufficient. This was seen from the selected human resources according to their fields. However, it was not only the human resources of the Agency of Women's Empowerment, Child Protection, Population and Family Planning, for its synergy to local government units related 5 clusters were also considered optimal as there were numbers of activities supporting the fulfillment of children's rights programs.

In terms of budget, for the implementation of this policy, it came from the Local Government Budget and also the funding support from the Ministry of Women Empowerment and Child Protection for children's creativity space. And as for the infrastructure that supported the implementation of this policy itself, it was also quite sufficient; although there were still a few parties that were not really attentive to the concept of children's rights in which that there were still some public places that do not consider the importance of children. 


\section{The Environment of the Implementation}

\section{The Powers, Importance, and Strategies of the Actors Involved}

There are several influential factors related to the implementation of this policy, from the factor of power to the importance and strategies of the policy implementers in order to make the policy run well. Therefore, from the power or strength in the hands of the head of the Agency of Women's Empowerment, Child Protection, Population and Family Planning service, in order that the programs carried out well, they also needed to work together with local government units related to the 5 clusters of the development of Child Friendly City in the Local Action Plan for the Development of Child Friendly City of Palangka Raya in 20142018. In the implementation of this policy, the Agency of Women's Empowerment, Child Protection, Population and Family Planning tried to socialize the programs of the Child Friendly City to all related local government units so that each unit can pay more attention to the concepts of children's rights in each of their programs and its activities. The strategies of each related local government unit in these 5 clusters are also very influential in the success of this policy. Some examples of the strategies are that the Social and Employment Service to socialize non-violence and apply anti-violence modules to schools as a strategy to fulfill children's rights in environment sector, Department of Education, Youth and Sports to socialize to the teaching staff about friendly ways of teaching the children and equip the facilities and infrastructure so that children can comfortably learn as a strategy to fulfill children's rights in the field of education, and as for Child Protection Institution to provide guidance, consultation, legal counseling about legal rights and obligations, mentoring and establishing partnership network with other parties as a strategy to fulfill the rights of children in the field of protection. Given these strategies, of course, it is hoped that the chances for the success of the policy of Child Friendly City in Palangka Raya can be greater.

\section{The Characteristics of Agencies and Regimes Existed}

From the results of study found by the researchers, it can be understood that the City Government, in this case the Mayor of Palangka Raya, expects all programs issued by the local government units support the vision and mission of the mayor.This includes the program of Child Friendly City which is expected to be able to prosper the society especially in fulfilling the rights of children.

\section{Compliance and Responsiveness}

The implementers of the policy play an important role in the success of a policy implementation. Without an executor, then a program can not be executed. Thus, the implementers really determine the success of a policy that is executed.

The response of the implementers to Mayor Regulation Number 17/ 2013 in which not only the Agency of Women's Empowerment, Child Protection, Population and Family Planning but also all related local government units within 5 clusters of working units listed in Local Action Plan of Development of Child Friendly City in Palangka Raya in 2014-2018 in performing their duty reflect good responses and they are also well aware that the children's rights are important in every program or activity that will be made. Although there are some discrepancies but the overall, the level of compliance and responsiveness of the implementers of this policy shows obedience. 


\section{Building Common Understanding as a Form of Collaborative Policy}

The collaborative process is an adaptive process where different opinions from different parties eventually result in a consensus. Anshell and Gash (2008) attempted to map out a model illustrating how collaborative processes occur. The collaborative process according to this model consists of various stages: starting from face-to-face dialogue, trust building, commitment to the process, sharing the understanding, and then the formation of intermediate outcomes. This stage is a cycle, so that there is a learning process in it. Innes and Booher (2010) developed the DIAD Network Dynamic model to demonstrate that the collaborative process represents a collaborative network where there is a diversity, interdependence and authentic dialogue within it. This means that: first, collaborative networks have a diversity of agents; second, agents are in a situation capable of meeting each other's interests and being aware of their interdependence; and third, there is an authentic dialogue where communication flows through the network accurately and reliably among the participants. In the authentic dialogue, there is reciprocity, relationships, learning, creativity, and generating adaptation of existing systems. This means that the participants (actors) speak representing the interests of the group, respect each other, and speak accurately. Of course, this requires trust, commitment, and understanding among actors.

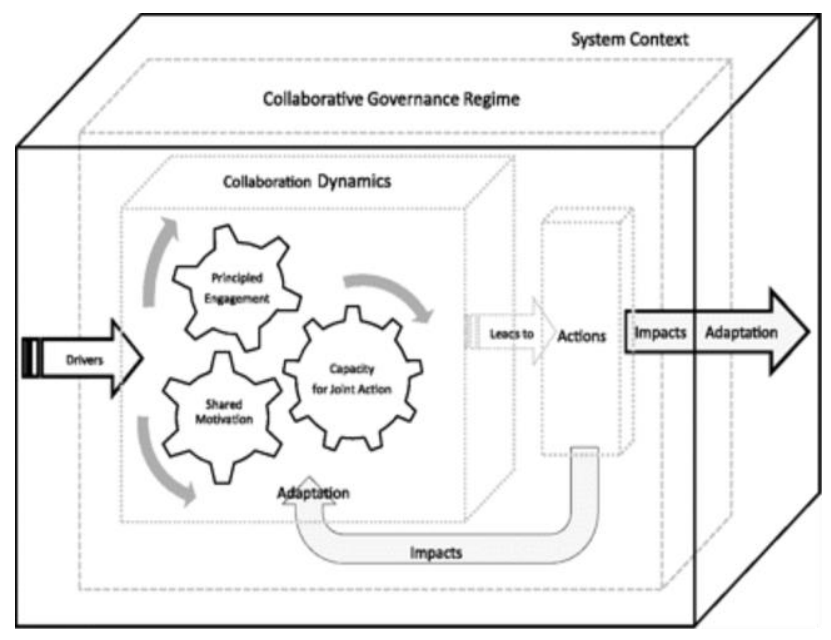

Source : The Integrative Framework For Collaborative Governance (Balogh, 2011: 6)

Referring to the collaborative model in the Balogh idea (2011) and the Anshell and Gash (2007) notions of Innes and Booher (2010 that collaborative policy strongly supports the principle of benefit and efficiency in the implementation of the Palangka Raya City Government policy. Although in Mayor Regulation Number 17/2013 has explicitly explained that the executor is the whole local government units, but in the mayor regulation, it has not shown the collaborative implementation of the work among local government units. This also firmly states that, in the field, the collaborative implementation did not happen. In the other management section, the researchers also hold that each local government unit carries a sectoral importance in the implementation process so that it will overlap in programs and activities, including budgeting. Collaborative policy patterns are particularly effective in solving resource problems, especially in budgetting. 


\section{Conclusion}

Based on the results of the research and discussion described in the previous chapters, the researchers draw conclusions from the results of research conducted on the Agency of Empowerment of Society, Women, Child Protection and Family Planning in Palangka Raya about the Implementation of Palangka Raya Mayor Regulation Number 17/2013 on Child Protection in Creating a Child Friendly City and the factors that influence it:

1. The Implementation of the policy of Palangka Raya Mayor Regulation Number 17/2013 on Child Protection in Creating Child Friendly City has been done in accordance with the Local Action Plans for the Development of the Child Friendly City of Palangka Raya in 2014-2018. Although categorized as well, the process of the implementation of this policy is still less than the maximum. This can be seen from some unconformities done by the executors of the programs, since there are still many parties that less care about the concept of the rights of children.

2. The supporting factors of this policy is the comprehension of the related local government units associated with the working units of the development of the Child Friendly City in arranging the program and the activities, there are even some local government units who have been running the program of Child Friendly City without the socialization of the Agency of Women's Empowerment, Child Protection, Population and Family Planning of Palangka Raya. As for the inhibiting factors are the limited funds available and the resources are still lacking. The limited availability of funds is the reason why the policy is not that imperative since there is no special funding for programs and the activities related to the fulfillment of the rights of children in each local government unit from the Agency of Women's Empowerment, Child Protection, Population and Family Planning.

3. The collaborative management still does not have a clear working arrangement, so the local government units still do the implementation based on their sectoral importance. The Local Government of Palangka Raya needs to implement a collaborative model of policy implementation starting from the aspects of the rule guided by all local government units in the implementation process in the field.

\section{References}

Anshell dan Gash. (2007). Collaborative Governance in Theory and Practice, Journal of Public Administration Reesearch and Theory. Published by Oxford Unversity Pres. Halaman 544

Balogh,S,dkk. (2011). An Integrative Framework for Collaborative Governance, Journal of Public Administration Research and Theory 22: 1-29 halaman 6

Idrus, Muhammad. (2009). Metode Penelitian Ilmu Sosial.Cetakan Kedua. Yogyakarta: PT. Gelora Aksara Pratama.

Innes, J., \& Booher, D. (2003). Collaborative policymaking: Governance through dialogue. In M. Hajer \& H. Wagenaar (Eds.), Deliberative Policy Analysis: Understanding 
Governance in the Network Society (Theories of Institutional Design, pp. 33-59). Cambridge: Cambridge University

Nugroho, Riant. (2011). Public Policy: Dinamika Kebijakan-Analisis Kebijakan- Manajamen Kebijakan. Jakarta: Elexmedia Komputindo.

Santosa, Panji. (2012). Administrasi Publik: Teori dan Aplikasi Good Governance. Bandung: PT. Refika Aditama.

Subarsono, AG. (2005). Analisis Kebijakan Publik: Konsep, Teori dan Aplikasi. Yogyakarta:

Pustaka Pelajar.

Sugiyono. (2011). Metode Penelitian Administrasi. Bandung: Alfabeta. . (2013). Metode Penelitian Kuantitatif, Kualitatif dan R\&D. Bandung: Alfabeta.

Winarno, Budi. (2014). Kebijakan Publik: Teori, Proses dan Studi Kasus: Cetakan Kedua. Yogyakarta: CAPS.

\section{Regulations}

PERMEN PP/PA No. 11 Tahun 2011 Tentang Kebijakan Pengembangan Kota Layak Anak PERWALI Kota Palangka Raya No. 17 Tahun 2013 Tentang Perlindungan Anak dalam mewujudkan Kota Layak Anak

\section{Internet}

http://www.ykai.net/index.php?view=article\&id=97:kota-layak-anak, diakses tanggal 23 September 2016

http://jdih.kalteng.go.id/index.php?r=produkHukum/view\&id=296\&title=Tugas

Pokok+Dan+Fungsi+Badan+Pemberdayaan+Perempuan\%2C+Anak+Dan+Ke luarga+Berencana+Provinsi+Kalimantan+Tengah, Diakses tanggal 23 September 2016

http://www.menaranews.com/2017/03/24-hak-anak-sebagai-syarat-pemko-jadi-kota-layakanak, diakses tanggal 23 september 2016

\section{Document}

Badan Pusat Statistik Kota Palangka Raya. 2013. Statistik Daerah Kecamatan Pahandut 